\title{
Menes caldera, a highly active site of brine seepage in the Eastern Mediterranean sea: "In situ" observations from the NAUTINIL expedition (2003)
}

\author{
C. Huguen ${ }^{\mathbf{a}, \mathbf{b}}$, J.P. Foucher ${ }^{\mathbf{b},{ }^{*}}$, J. Mascle $^{\mathbf{c}}, \mathrm{H}$. Ondréas ${ }^{\mathbf{b}}, \mathrm{M}$. Thouement ${ }^{\mathbf{b}}$, S. Gontharet ${ }^{\mathrm{d}}, \mathrm{A}$. \\ Stadnitskaia $^{\mathrm{e}}$, C. Pierre ${ }^{\mathrm{d}}$, G. Bayon ${ }^{\mathrm{b}}$, L. Loncke ${ }^{\mathrm{f}}$, A. Boetius $^{\mathrm{g}}$, I. Bouloubassi ${ }^{\mathrm{d}}$, G. de Lange $^{\mathrm{h}}$, J.C. \\ Caprais $^{\mathbf{b}}$, Y. Fouquet ${ }^{\mathbf{b}}, \mathrm{J}$. Woodside', S. Dupréd ${ }^{\mathrm{d}}$ and the NAUTINIL Scientific Party
}

\author{
a LEGEM, Université de Perpignan, 52 Av Paul Alduy, 66280 Perpignan, France \\ ${ }^{\mathrm{b}}$ IFREMER, BP 70, 29280 Plouzané, France \\ ${ }^{c}$ Géosciences-Azur, Observatoire Océanologique de Villefranche, BP 48, 06235 Villefranche/Mer, \\ France \\ d LOCEAN, UPMC, UMR 7159, 4 Place Jussieu, 75252 Paris cedex 05, France \\ e NIOZ, P.O. Box 59, 1790 AB Den Burg, Texel, The Netherlands \\ ${ }^{f}$ UPJV Faculté des Sciences, Laboratoire Sciences de la Terre, 33 Rue St Leu, 80000 Amiens, France \\ ${ }^{9}$ Max Planck Institute for Marine Microbiology, Celsiusstr. 1, D-28359 Bremen, Germany \\ ${ }^{\mathrm{h}}$ Utrecht University, Department of Earth Sciences, P.O. Box 80.021, 3508 TA Utrecht, The \\ Netherlands \\ 'Vrije Universiteit, Amsterdam, De Boelelaan, 1085, 1081 HV Amsterdam, The Netherlands \\ * Corresponding author: J.P. Foucher, Tel.: +33 2982242 69; fax: +33 2982245 70, email address : \\ ifoucher@ifremer.fr
}

\begin{abstract}
:
This paper reports the first "in situ" seafloor observations of fluid escape structures in a fault-controlled caldera-type depression of about $8 \mathrm{~km}$ diameter, named the Menes caldera, in the Eastern Mediterranean sea off Egypt (western province of the Nile Deep Sea Fan). A detailed analysis of seven Nautile dives, performed during the Nautinil cruise in 2003, focused on determining the nature, origin, importance, mechanisms and environmental impacts of the fluid escape processes from the geological observations.

Seafloor maps, constructed from direct visual observations and video records made from the submersible, and sampling results, for three mud volcanoes of the caldera, Cheops, Chephren and Mykerinos show differences in activity but many common characteristics. The three volcanoes show a crater-like depression. The study reveals a strong contrast between Mykerinos, where no seepage activity was found, and the craters of Cheops and Chephren, where an intense activity of brine seepage was discovered.

On Cheops, a dome of dark grey mud raises slightly above the brine surface in the central part of the brine lake, and shows numerous circular vents of 1-2 m diameter that become gradually colonized by microbial mats. Chephren hosts a deep $(>200 \mathrm{~m})$ and warm $\left(45^{\circ} \mathrm{C}\right)$ brine lake. Alternations of areas void of or covered with microbial mats at the surface of the Chephren brine lake indicate large surface disturbances that may result from the occurrence of several active vents at the bottom of the lake. A special feature at Chephren is a brine overflow at the western edge of the crater, also indicative of the very high activity of brine seepage.

The Nautinil observations indicate that the Menes caldera in the Eastern Mediterranean is a highly active site of brine seepage. Growth faults rooted in pre-Messinian sediment layers provide pathways for warm fluids to escape pressurized source levels below the Messinian salt.
\end{abstract}




\section{Introduction}

The Nile Deep Sea Fan (NDSF) is a thick sedimentary wedge mostly built up since the Messinian salinity crisis (late Miocene) by the deposition of Pliocene and Quaternary sediments over a large segment of the ancient (late Jurassic to early Cretaceous) passive margin of Egypt (Fig. 1a). The sedimentary pile appears intensively deformed, due to both the complex geodynamic setting of the Eastern Mediterranean, and important salt-related tectonic processes triggered by the presence of thick ductile evaporite layers underlying most of the NDSF. A large number of fluid escape structures, have been discovered during the last decade over the Egyptian continental slope (Coleman et Ballard, 2001; Loncke et al., 2004). Different fluid escape structures on the NDSF have been identified by means of geophysical tools (Fig. 1b). These can be classified most simply as (a) sedimentary build-ups such as mud cones and flattened mud pies, varying from several hundreds of metres to several kilometres in diameter and several tens of metres high, (b) gas chimneys of several km in diameter, which appear as seismically transparent columnar bodies and (c) fields of pockmark fields, each of a few metres to tens of metres in diameter and a few metres deep (Loncke et al., 2004).

As a follow up to the geophysical analysis, the Nautinil cruise (2003) collected ground-truth data providing further information on the nature, origin, importance, mechanisms and environmental impacts of the NDSF fluid escape structures. In this paper, we present the main seafloor geological characteristics and seep features of three prominent mud mounds of the Menes caldera in the western province of the NDSF based on the observations made during seven Nautinil dives. Nautinil observations showed these mud mounds to be mud volcanoes. Therefore the three mud mounds will be hereafter referred to in this paper as mud volcanoes.

\section{Geological framework}

\subsection{The Nile Deep Sea Fan}

The Nile Deep Sea Fan (NDSF), covering the Egyptian continental margin over more than $100000 \mathrm{~km} 2$ (Fig. 1), corresponds to a fairly thick sedimentary wedge, resulting from successive terrigenous inputs by the Nile river since the late Miocene (Salem, 1976; Dolson et al., 2005; Loncke, 2002; Loncke et al., 2006). This huge sedimentary system is located in the Eastern Mediterranean, where the geodynamic framework (Fig. 1a) is today characterized by a complex interaction of various plates including (1) the northwards moving Arabic and African plates, disconnected by the (2) Sinai microplate, and involved in a precollision process with the (3) SW rotating Aegean-Anatolian microplate, itself disconnected from the (4) Eurasian plate by the North Anatolian strike-slip fault zone (Mc Kenzie, 1972; Le Pichon et al., 1995; Mascle et al., 2000, McClusky et al., 2000).

Interacting with such a complex geodynamic framework, layers up to $3 \mathrm{~km}$ thick of ductile evaporites (Camera, 2006; Loncke et al., 2006), deposited during the Messinian salinity crisis over most of the Eastern Mediterranean deep basins, triggered spectacular salt-related deformations over the NDSF (Gaullier et al., 2000; Loncke, 2002; Loncke et al., 2006). As a consequence of both crustal and sediment cover tectonics, the NDSF appears as a strongly tectonized system.

A detailed morphostructural study of this complex sedimentary body recently completed on the basis of sedimentary sampling, multibeam bathymetry and seismic data (Bellaiche et al., 1999, 2001; Gaullier et al., 2000; Bellaiche et al., 2001; Mascle et al., 2001; Loncke, 2002; Loncke et al., 2004; Mascle et al, 2006) illustrates important lateral morphological contrasts across the NDSF (Fig. 1b). From east to west, four main provinces, characterized by highly 
contrasting morphostructural patterns controlled by the Messinian paleogeography, have been identified:

(1) South of Eratosthene seamount, an easternmost province (Levantine province) shows a gently ondulating seafloor which results from the folding of thin Pliocene and Quaternary sediments above the ductile Messinian evaporite layer (Gaullier et al., 2000; Netzeband et al., 2006).

(2) An eastern province, characterized by important recent to present day deformation, expressed along slope as polygonal mini-basins, salt ridges and short wavelength folds. There, the tectonic pattern appears mainly controlled by the presence of a NWSE tectonic corridor, combined with thick underlying Messinian salt deposits, progressively stacking and thickening downslope (Gaullier et al., 2000; Loncke et al., 2006).

(3) A central province, covering a large area of the NDSF, rather characterized by a chaotic seafloor surface, due to successive sedimentary instabilities (Loncke et al., 2002). In this area, most of the identified growth faults seem to be sealed by debris flow deposits, except at its boundary with the eastern province, where recently active growth faults are observed along the Messinian platform.

(4) Finally, a western province, intensely cut by the Rosetta active channel-levee system (Bellaiche et al., 2001; Ducassou, 2007), where large amounts of turbiditic sediments were deposited and progressively incorporated into the Mediterranean ridge outer domain (Huguen et al., 2001). Upslope, this area shows active growth faults, resulting from the progressive downslope gliding of the sedimentary pile on the Messinian ductile layers.

\subsection{Fluid escape structures on the NDSF}

Three types of fluid escape structures can be distinguished over the NDSF, according to parameters including the morphostructure, backscatter characteristics, and relationships with the sedimentary and tectonic setting (Fig. 1b) (Loncke, 2002; Loncke et al., 2004. Dupré et al., 2006; Mascle et al., 2006),

Within the western province, a large number of small mud cones (diameters from $100 \mathrm{~m}$ to 1 $\mathrm{km}$, and elevations from 10 to $60 \mathrm{~m}$ ) have been identified at the foot of the growth fault system. These structures are generally characterized by a weak backscatter except for the summit area of some of them, where a more intense backscatter was identified, indicating 
probable recent mud/fluid expulsions, or the presence of diagenetic carbonate crusts. Most of these structures show typical acoustically transparent seismic facies and have been identified near growth faults, rooted in pre-Messinian layers and believed to act as preferential pathways for upward fluid migrations (Loncke et al., 2004). The distribution of these fluid escape features appears thus closely controlled by salt tectonics, responsible, besides the growth fault emplacement, for a thinning of the sealing evaporite units and a thickening of the Plio-Quaternary sediments, both processes increasing the overpressure within deep fluid reservoirs (Loncke et al., 2004).

Along the NDSF upper slope, broad gas chimneys are observed, with diameters reaching 5 $\mathrm{km}$ and characterized by slightly positive morphologies, often surrounded by depressed rims, and displaying high backscatter centres, interpreted as main areas for fluid and mud discharge (Loncke, 2002, 2006; Dupré et al., 2006, 2007). These structures are only observed in areas where thick Messinian salt layers are absent, and nearby or in connection with partly reactivated fault systems (Loncke et al., 2004, Camera, 2006; Dupré et al, 2007). In seismic data they appear as seismically transparent columnar bodies, which indicates gasrich sediments, as confirmed by the recovery of strongly degassing sediments by piston coring (Loncke, 2002) and by direct in situ observations (Dupré et al., 2007).

Finally, fields of pockmarks particularly well expressed over the central and eastern provinces of the NDSF, seem to represent the most widely observed fluid venting structures in these two provinces (Loncke et al., 2004), in close relation with sediment destabilization in the central province (Bayon et al., 2009, this volume).

\subsection{The Menes caldera}

Numerous mud cones have been identified within a wide area (about $50 \mathrm{~km}$ by $100 \mathrm{~km}$ ) at the foot of the NDSF western province continental slope (Fig. 2). High resolution multibeam bathymetry (Loncke et al., 2004) shows that these structures have conical shapes, with diameters between 200 and $1000 \mathrm{~m}$, and elevations of a few tens of metres. Some of the mud cones show a collapsed summit, which forms a crater-like depression at the top of the structure (Fig. 2a). These features appear either isolated and scattered on the NDSF seafloor or located within broad depressions, often referred to as "calderas" (Figs. 2 and 3). Unlike several mud volcanoes within the Eastern Mediterranean (i.e. Mediterranean Ridge) (Woodside and Volgin, 1996; Huguen, 2001; Huguen et al 2004; 2005), the western NDSF mud cones do not generally show a very high acoustic backscatter (Fig. 3a), although a slightly stronger signal than from the surrounding seafloor is noticed, which could indicate active fluid venting, recent mud flows or diagenetic carbonate crusts.

The Menes caldera (Fig. 3) is one of the most clearly observed "caldera" structures on the bathymetric map of the NDSF (Sardou and Mascle, 2003). It is a large circular seafloor depression of about $8 \mathrm{~km}$ in diameter with steep surrounding walls, except to the north, and a basin floor depth of about $3020 \mathrm{~m}$ (Fig. 3b). A seismic reflection profile across this structure (see Fig. 6a in Loncke et al. 2004) indicate that the southern edge of the caldera is fault controlled. Active faulting could be related to underlying salt movement (Loncke et al., 2004). There are four or five well-defined cones around the edge of the structure and three within the caldera itself, all with a low local relief from 10 to $40 \mathrm{~m}$ and 500-1000 m widths (Fig. 3). Some of them show a slightly elevated backscatter at the summit (Fig. 3a), suggesting recent mud flows or the existence of carbonate crusts at the seafloor.

\section{Nautinil expedition: Data and methodology}

Twenty two dives with the manned submersible Nautile were carried out during the Nautinil scientific expedition of the research vessel L'Atalante in the Eastern Mediterranean in September-October 2003. Dives were located in two main study areas: the crest of the 
central Mediterranean Ridge, south of Crete (4 dives), and the NDSF, offshore Northern Egypt (18 dives), in water depths ranging from $500 \mathrm{~m}$ to $3000 \mathrm{~m}$. Dive targets on the NDSF had been all selected on the basis of data collected during previous surveys in this area, principally the Prismed2, Fanil and Medisis cruises (Bellaiche et al., 1999, 2001; Mascle et al., 2006).

Main NDSF dive target areas during Nautinil were the pockmarks fields of the central Nile fan middle slope (Loncke et al., 2004; Bayon et al., 2009, this volume), mud volcanoes of the Eastern continental slope (Loncke et al., 2004; Dupré et al., 2007), and the Menes caldera mud volcanoes, to which seven dives were dedicated.

The Nautile was positioned with a combination of long base line seafloor positioning (using 3 beacons deployed at the boundary of the diving area) and ultra short base line positioning (shipborne POSIDONIA underwater positioning system). Corrected dive tracks took into account dead-reckoning positions estimated from records of the submersible speed and heading. Nautile thus provided precisely positioned observations and samples. The video analyses were mainly completed using the ArcGIS-based ADELIE software (from Ifremer).

Sediment cores (push-cores and blade-cores) and authigenic carbonates were collected in the Menes Caldera during the Nautile dives. The inorganic geochemical composition of authigenic carbonates and sediments was determined by wavelength dispersive X-ray fluorescence (WD-XRF) analysis of fusion beads for major elements. Details on the methods and results of the mineralogy and geochemistry analyses of authigenic carbonates are reported elsewhere (Gontharet et al., 2007).

Seafloor bathymetry and acoustic backscatter imagery used for Nautinil and shown in this paper were from previous cruises Prismed2 (1998) using the EM 12 Dual SIMRAD multibeam echosounder of R/V L'Atalante and Fanil (2000) using the EM 300 Dual SIMRAD system of R/V Le Suroît (Huguen, 2001; Loncke et al., 2002b; Sardou and Mascle, 2003).

\section{Results}

Two exploratory dives (Dives 3 and 4, Fig. 4a) visited the three mud cones of the Menes caldera, which were then identified as mud volcanoes and subsequently named Cheops, Chephren and Mykerinos after the three main pyramids at Giza (Figs. 4 to 7). Five further dives were dedicated to more detailed observations and sampling (Dives 16 to 20, Fig. 4a).

\subsection{Main features of the Menes caldera seafloor}

A major result of the Nautinil expedition was the discovery of large brine lakes on the summits of Cheops and Chephren, which occupy crater-like seabed depressions. Nautinil observations pointed to a high current activity of fluid emissions on the summits of the two mud volcanoes. In contrast, Mykerinos showed an empty crater and no evidence of current fluid escape.

The relatively high acoustic backscatter (Fig. 3a) recorded from previous multibeam surveys on the flanks of the mud volcanoes, did not appear to correlate with recent mud flows observed during the dive. Instead, dive observations indicated a continuous seabed cover of uniformly light brown pelagic sediment.

Carbonate crust patches, colonized by small tube worms and polychaete, and covered with bivalve shells, were observed to occur locally; on the northern flank of Cheops (4c), on a small relief in the basin floor to the west of Cheops (Fig. 4b), and along the southern rim of the caldera (Fig. 4d), as well as within the Mykerinos central crater. Those observations may relate to some recent or past, localized activity of fluid seepage in the Menes caldera, outside the highly active summits of Cheops and Chephren. 


\subsection{Cheops mud volcano}

\subsubsection{Seafloor observations}

Cheops lies near the centre of the Menes caldera and rises approximately 40 metres above the basin floor (Figs. 3b and 4a). Its morphology is that of a truncated cone. From the floor of the Menes caldera to the summit of Cheops, a gentle slope covered by pelagic sediments leads to the sharp edge of the crater brine pond (Figs. 5a and $5 b$ top).

In a plan view of the summit of Cheops drawn from visual dive observations (Fig. 5a), briny mud venting appears to have formed an axial mud dome rising a few metres above the horizontal surface of the surrounding brine pond. Vents are typically circular with a 1-2 meter diameter, and colonized by a white fluffy material presumably of bacterial origin (Figs. $5 \mathrm{c}$ and $5 d$ ). We interpret the darker mud vents, as the most recently active spots of venting, the surface of which have not yet been colonized by bacteria. The concentric different stages of colonization that were observed at a few vents (Fig. 5d) are interpreted to indicate the occurrence of successive, distinct events of venting at a single vent.

A 1-2 $\mathrm{m}$ thick layer of clear brine was observed to fill in the peripheral outer part of the crater (Fig. 5a). Black streaks (Fig. 5b bottom) at the outer wall of the brine pond may indicate chemical and/or microbial reactions, such as FeS precipitation, between the brine and the adjacent sediment cover of the flank of the volcano. Brine shearing at the edge of the pond appeared to induce active erosion, which could lead to a progressive migration outwards of the edge of crater with time.

Whitish filamentous was observed at many locations of the brine pond either suspended in the brine or lying on the bottom of the pond. This material was often slowly moving, thus suggesting that the brine in the pond was also moving. The movement could be caused by brine inflow from active bottom vents and/or brine outflow at its margin (possibly in the eastern part of the Cheops summit that was not explored).

A single temperature measurement in the clear brine at the northern edge of the crater indicated a weak positive temperature anomaly of $0.3-0.5{ }^{\circ} \mathrm{C}$ above the bottom water temperature of $14.0^{\circ} \mathrm{C}$.

\subsubsection{Sampling results}

The Cheops mud was so fluid that almost all attempts to sample it with a push core or a blade corer failed. A blade core taken at the northeastern edge of the brine lake sampled a very dark grey, homogeneous, strongly gas-saturated mousse-like mud breccia with high silt/sand content and numerous millimetre sized black semi-consolidated clayey clasts (Fig. 8a). The sample was characterized by a strong smell of hydrogen sulphide and oil. Abundant small polychaete worms were observed within the topmost intervals of the mud breccia. Brine fluids sampled at two positions showed a $\mathrm{pH}$ of 6.3-6.7, and $\mathrm{H} 2 \mathrm{~S}$ and $\mathrm{CH} 4$ concentrations of 0.2 and $0.1-2.9 \mathrm{mM}$ respectively. The salinity varied between $130-310 \%$, and the sulphate concentration was $15-24 \mathrm{mM}$.

\subsection{Chephren mud volcano}

\subsubsection{Seafloor observations}

Chephren (Fig. 6a) resembles Cheops in several aspects: its overall morphology, its flanks covered by pelagic sediment, the occurrence of a brine-filled crater on its summit, and an intense microbiological activity associated with brine seepage (Omoregie et al., 2008; Omoregie et al., 2009, this volume). However, the brine lake at Chephren is much deeper than at Cheops; its depth could be at least 200 metres as estimated from the length of wire paid out during unsuccessful coring attempts in the central part.

A special feature at Chephren is a brine overflow area that we observed at the northwestern edge of the crater over a distance of several tens of metres (Fig. 6a). The area showed a 
greyish mud seabed, covered with threads of dark grey mud and whitish matter presumably of bacterial origin carried onto the outer edge of the crater by the brine overflow (Fig. 6b). Thin streams of clear brines were observed locally within the overflow area, with brine flow velocities visually estimated at a few centimetres per second. In the northernmost area, mushroom-like precipitates were observed to float on the muddy brine (Fig. 6c), in addition to the most commonly found filamentous materials Clear brines were also observed to flow or form small ponds at the eastern (Fig. 6d) and southern (Fig. 6f) edges of the crater.

The surface of the brine pond showed alternations of areas void of or covered by microbial mats (Fig. 6e). Some similarity was noted between the brine pond appearance and that of the central region of Cheops which was characterized by numerous small mud vents but, in the case of Chephren, observed brine surface disturbances, were much larger in size that at Cheops, up to several tens of metres across. These large-scale surface disturbances may reflect brine movements in the pond, possibly associated with active venting at the bottom of the crater.

\subsubsection{Warm brine temperature}

The brine temperature of the Chephren mud volcano was measured to be 38 and $45^{\circ} \mathrm{C}$ at two locations of the northwestern part of the lake. Using a value of $20^{\circ} / \mathrm{km}$ for the regional temperature gradient in the Nile deep sea fan outside the mud mounds (Dupré et al, 2007) and a seabed temperature of $14^{\circ} \mathrm{C}$ for the bottom water, a sediment temperature of $38-45^{\circ} \mathrm{C}$ would be reached at a depth of 1.1-1.6 km below the seabed. This may give a minimum estimate of the depth of the origin of the warm fluids forming the brines.

\subsubsection{Sampling results}

The brine filling the crater of Chephren had salt concentrations of $89-153 \%$. It contained high amounts of sulphide (0.5-7.2 mM), methane (0.6-2.5 mM) and sulphate (33.0-57.0 mM). An isolated, small brine seep was also discovered and sampled at the outer rim of Chephren. Here, the seafloor was covered with microbial precipitates of white and orange color (Omoregie et al, 2008) (Figs. 4e and f). Short push cores, NL18-PC1-(8) and NL-18-PC3(45), were taken from these mats and contained layers of grey silty clay and black soupy reduced sediment. Both cores were characterized by a strong smell of sulphide and showed relatively high microbial sulphate reduction rates, indicative of hydrocarbon seepage (Omoregie et al., 2009 this volume). Very high Fe (up to 23 wt\%) and S concentrations (up to $16 \mathrm{wt} \%$ ) from a blade core, NL18-BC1, taken at the same location are related to the presence of pyrite (Figs. 8b and 9). Blade core NL19BC1, taken at the western edge of the Chephren crater exhibits marked changes in the relative contents of $\mathrm{SiO}_{2}$ (16 to $\left.65 \mathrm{wt} \%\right)$ and $\mathrm{CaO}$ (1 to $38 \mathrm{wt} \%$ ) with depth (Fig. 10). Such large down-core variations are explained by the alternation of mudflow with high $\mathrm{SiO}_{2}$ contents and pelagic sediments with high carbonate contents. Blade core NL11BC2 taken at the eastern edge of the Chephren crater consistently shows high $\mathrm{SiO}_{2}$ contents and low $\mathrm{CaCO}_{3}$ contents that indicate a uniform composition of mud flow.

\subsection{Mykerinos mud volcano}

\subsubsection{Seafloor observations}

Like Cheops and Chephren, Mykerinos hosts a large and deep crater at its centre, which was found to be empty in contrast to the brine filled craters of Cheops and Chephren (Fig. 7a). The floor of the Mykerinos crater appeared quite bumpy, containing successive depressions, several metres wide, showing spots of thin carbonate pavements in the central part (Fig. 7c) and local coverage by light brown pelagic sediments (Fig. 7b). Coarser sediments and debris 
(Fig. 7d) were observed locally at the base of the steep inner slopes, indicating slope failure events. No evidence of current fluid flow activity was obtained during Nautinil (2003).

Several metres high scarps at the caldera wall to the south-east of Mykerinos (Fig. 7e) cut through layers of indurated sediments.

\subsubsection{Sampling results}

Pelagic sediments were recovered from the central crater floor (Fig. 8c). The topmost few centimetres correspond to a homogenous light brown silty marl, rich in foraminifera and shell debris, with a sharp boundary to an underlying dark greenish-brown mud full of foraminifera, shell debris and burrows filled with light grey clay. The abundance of shell debris could be related to a past fluid venting activity in Mykerinos.

\section{Discussion}

\subsection{Similarities and differences at Cheops, Chephren and Mykerinos mud volcanoes. A common model of formation?}

Cheops, Chephren and Mykerinos mud volcanoes show similar morphologies (truncated cone, comparable extents on the seabed, occurrence of a crater-like depression) but a major difference is in their activity. Cheops and Chephren were observed to be highly active seeps with expelled brines and muds forming thick ponds in the craters of the two mud volcanoes, whereas Mykerinos was observed to be currently inactive. Compared to other mud volcanoes of the Eastern Mediterranean, also associated with brine seepage, such as Napoli mud volcano (e.g Central Mediterranean Ridge, Huguen et al., 2004), Cheops and Chephren showed an unequalled vigour of brine flow. Their brines are generally more concentrated than those from the central Mediterranean Ridge (Napoli mud volcano and Nadir brine lake) but their sulfate concentrations are very similar (Charlou et al., 2003).

It may be questioned whether the absence of seepage at Mykerinos implies a mode of formation or functioning of this volcano that would be different from that at Cheops and Chephren. Observational evidence, including the finding of shell debris, points however to a past fluid activity at Mykerinos and brine seepage is therefore proposed to have been active at Mykerinos as well. Among possible explanations for a cease of seepage at Mykerinos, one could simply conclude that open fluid flow conduits under Mykerinos became sealed as a result of seabed deformation and subsequent re-organisation of the fluid flow channels in this region of the North-Egyptian slope in relation to the progressive gliding of the sedimentary pile on the Messinian ductile salt layers (Huguen et al., 2001).

We therefore suggest that Cheops, Chephren and Mykerinos are the seabed expression of a single, common model of formation of a mud volcano, found in the NDSF western region underlain by Messinian evaporites. The formation is triggered by the release of warm fluids flowing from over-pressurized pre-Messinian layers to the seabed along deep growth faults that pierce the evaporites (Fig. 11). The highly hypersaline nature of the brines sampled at both Chephren and Cheops gives support to the interpretation that the dissolved salts of brines are mostly issued from dissolution of Messinian evaporite layers (i.e. halite and gypsum) by ascending fluids from pre-Messinian depths. This is also supported by the presence of abundant euhedral gypsum crystals in several sediment samples taken at the surface of the three mud volcanoes (Fig. 9a). Gypsum saturated brines induced precipitation of this mineral within the sediments where reducing conditions were also promoting $\mathrm{H}_{2} \mathrm{~S}$ production via bacterial sulfate reduction and pyrite formation. Furthermore, sharp fault planes at the walls of the empty crater of Mykerinos could be viewed as an indication that the crater was formed through a process of collapse of the summit of the mud volcano. The collapse could have followed the dissolution of the underlying evaporites at a time of brine seepage activity. This mechanism of formation of the crater at Mykerinos, that might also be 
proposed for Cheops and Chephren, remains however highly speculative due to a lack of clear observational evidence in support of it.

Interestingly also, clear brines were observed to flow on the seabed or have accumulated next to dark muddy brines both at Cheops and Chephren. Dark muddy brines (often simply referred to as mud at Cheops) are expelled at the centre of Cheops, where the seabed slightly rises above a peripheral pond of contrasting, transparent, clear brines. The Chephren crater is filled with dark muddy brines, although clear brine flows were also observed locally at the periphery of the dark brine area. We hypothesize that there are distinct brine source with different properties because of distinct flow channels and different interactions of the brines with the sediment during their ascent to the seafloor. The flat surface of the crater pond at Chephren reflects a perfectly fluid mechanical behaviour of the erupted brines and mud. Instead, the gentle dome slightly rising above the peripheral brine pond that we observed at the centre of Cheops suggests a slightly viscou behaviour of the erupted material, probably related to a lower content of the mud in brine.

\subsection{Authigenic carbonates. What do they tell us?}

Authigenic carbonates encrust the seafloor at several locations within the Menes caldera (Fig. 4; see section 4.1). In addition, unconsolidated sediments contain millimetre-size carbonate and pyrite concretions, and numerous millimetre- to centimetre-size euhedral gypsum crystals as shown for Chephren in Fig. 9a.

Petrographic observations of carbonate crusts and micro-concretions show that they are formed by a microcrystalline carbonate cement including terrigenous and biogenic components (Figs. 9b and c). Aragonite occurs either as microcrystalline cement or as large acicular crystals infilling voids (Fig. 9d). Pyrite was found as euhedral parabolic pyrite crystals forming framboids in close association with crystals of aragonite. X-ray analyses indicate that carbonate crusts are composed of low-Mg calcite, aragonite, high-Mg calcite and minor amounts (less than 5\%) of dolomite.

Low $\delta^{13} \mathrm{C}$ values of carbonate crusts (from $-41.08 \%$ to $-29.83 \%$ ) indicate that methane was the dominant carbon source during carbonate precipitation. The $\delta^{18} \mathrm{O}$ values of carbonate crusts $\left(2.68 \%\right.$ o to $3.07 \%$ ) are very close to the $\delta^{18} \mathrm{O}$ values $(-3 \%)$ expected for aragonite and high-Mg calcite precipitating in isotopic equilibrium with modern eastern Mediterranean bottom water (Gontharet et al., 2007).

These results demonstrate that authigenic carbonates precipitated within reduced sediments where pore waters corresponded to bottom water in which bicarbonate ions were produced by microbial anaerobic oxidation of methane associated with bacterial sulphate reduction (Ritger et al., 1987).

\subsection{Variable seabed acoustic backscatter in the Menes caldera versus dive observations}

It is worth noting in Fig. $3 a$ that Cheops and Mykerinos are associated with a high backscatter over seabed surfaces that greatly extend beyond surfaces of the craters of the two mud volcanoes. At Cheops, the high backscatter extends over a roughly circular area 2-3 $\mathrm{km}$ across whereas active mud and brine flow appears to be restricted to an area less than 1 $\mathrm{km}$ across. At Mykerinos, the crater is less than $1 \mathrm{~km}$ across whereas the high backscatter area is twice as wide and clearly extends over the flank of the mud volcano. In contrast, Chephren is associated with a dominant low backscatter except at the very spot of the brinefilled crater (Fig. 3a). We interpret the low backscatter as due to the occurrence of a seabed sediment cover made of low-backscattering pelagic sediments whereas the high backscatter is interpreted to indicate highly reflective mud breccias exposed at the seabed or lying under a thin cover of pelagic sediments. Assuming then that the thickness of pelagic sediments could be viewed as a measure of the time elapsed since the last mud eruption event at a mud volcano, which is thought to be likely the case if erosion or gravity failure does not affect 
significantly this thickness, the high backscatter at Mykerinos would imply a thin pelagic sediment cover, thus suggesting that this volcano with a currently empty crater has been inactive for only a short while. On the contrary, the low backscatter of Chephren's flanks would indicate a long time of quiescence, before the present-day observed high seepage activity.

\section{Conclusion}

Dive observations made during the Nautinil expedition have discovered active brine seepage at the Cheops and Chephren mud volcanoes of the Menes caldera in the western region of the Nile deep-sea fan, whereas Mykerinos was found to be inactive. Crater-like depressions occupy the summits of the three volcanoes, filled with warm brines at the actively seeping Cheops and Chephren. Dissolution of the underlying Messinian evaporites by warm fluids ascending from pre-Messininan depths along growth faults of the Egyptian continental slope is the likely explanation of the hypersalinity of the brines and may also account for the formation of the craters.

The highly active Cheops and Chephren mud volcanoes and the inactive Mykerinos illustrate different stages of activity (Fig. 11) of a type of mud volcano, associated with brine seepage, that may commonly occur in the NDSF. Seabed swath mapping surveys have revealed a large number of mud mounds in the western region of the NDSF underlain by Messinian evaporites (Loncke et al., 2004). Several of these mounds, mostly unexplored, could well be mud volcanoes of the same type as Cheops, Chephren or Mykerinos, investigated in detail during the Nautinil expedition.

\section{Acknowledgements}

The Nautinil cruise was the first of a series of three expeditions carried out in the framework of the Mediflux Research Cooperative Project (2003-2007) between the Max Planck Institute for Marine Microbiology of Bremen in Germany, Vrije Universiteit Amsterdam, Utrecht University and NIOZ in the Netherlands and the University of Paris and Ifremer in France, as part of the European Science Foundation (ESF) EUROCORES Euromargin programme. Nautinil (2003) was followed by the Mediflux cruises: Mimes (2004) of the Dutch research vessel Pelagia and BioNil (2006) of the German research vessel Meteor. The Mediflux RCP was funded by DFG in Germany, NWO in the Netherlands (programme number 855.01.030), CNRS/INSU and Ifremer in France, under the ESF Euromargin coordination. We thank the officers and crew of the research vessel L'Atalante, the technical support team and pilots of Nautile for their magnificent support during Nautinil, and the scientific crew for help with work at sea and in the laboratory.

\section{References}

Bayon, G., Loncke, L., Dupré, S., Caprais, J.-C., Ducassou, E., Duperron, S., Etoubleau, J., Foucher, J.-P., Fouquet, Y., Gontharet, S., Henderson, G.M., Huguen, C., Klaucke, I., Mascle, J., Migeon, S., Olu-Le Roy, K., Ondréas, H., Pierre, C., Sibuet, M., Stadnitskaia, A., and Woodside, J. Fluid seepage on an unstable margin: The case of the Centre Nile fan. Marine Geology. (this volume)

Bellaiche, G., Zitter, T., Droz, L., Gaullier, V., Mart, Y., Mascle, J., and the Prismed Equipe Scientifique France, 1999. Le Cône sous-marin profond du Nil: principaux résultats de la 
campagne PRISMED II du N.O. L'Atalante. Comptes Rendus de l'Académie des Sciences. Série II. Sciences de la Terre et des Planètes 329 (10), 727-733.

Bellaiche, G., Loncke, L., Gaullier, V., Mascle, J., Courp, T., Moreau, A., Radan, S., Sardou, O., 2001. Le cône sous-marin du Nil et son réseau de chenaux profonds: nouveaux résultats (campagne Fanil). Compte Rendus de l'Académie des Sciences. Série II. Sciences de la Terre et des Planètes 333 (7), 399-404.

Camera, L., 2006. Structure profonde de la marge passive Egyptienne au large du Nil, Thèse de doctorat de l'Université P. et M. Curie (Paris 6), 161 pp.

Coleman, D.F. and Ballard, R.D., 2001. A highly concentrated region of cold hydrocarbon seeps in the southeastern Mediterranean sea. Geo-Marine Letters 21, 162-167.

Dolson, J.C., Boucher, P.J., Siok, J., Heppard, P.D., 2005. Key challenges to realizing full potential in an emerging giant gas province: Nile delta/Mediterranean offshore, deep water, Egypt. In: Dore' , A.G., Vinning, B.A. (Eds.), Petroleum Geology: North-West Europe and Global Perspectives. Proceedings of the 6th Petroleum Geology conference. Geological Society, London, pp. 607-624.

Ducassou, E., Capotondi, L., Murat, A., Bernasconi, S. M., Mulder, T., Gonthier, E., Migeon, S., Duprat, J., Giraudeau, J., Mascle, J., 2007. Multiproxy Late Quaternary stratigraphy of the Nile deep-sea turbidite system - Towards a chronology of deep-sea terrigeneous system. Sedimentary Geology 200, 1-13.

Dupré, S., Woodside, J. M., Foucher, J.-P., De Lange, G., Mascle, J., Boetius, A., Mastalerz, V., Stadnitskaia, A., Ondréas, H., Huguen, C., Harmegnies, F., Gontharet, S., Loncke, L., Deville, E., Niemann, H., Omoregie, E., Olu-Le Roy, K., Dählmann, A., Caprais, J.-C., Prinzhofer, A., Sibuet, M., Pierre, C., Sinninghe Damsté, J., and the NAUTINIL Scientific Party, 2007. Seafloor geological studies above active gas chimneys off Egypt (Central Nile Deep Sea Fan). Deep-Sea Research I 54, 1146-1172.

Dupré, S., Woodside, J.M., Klaucke, I., Mascle, J., Foucher, J.-P., and the NAUTINIL \& MIMES Scientific Parties, 2006. Multi-scale seafloor mapping of active seep-related structures, offshore Egypt. In: CIESM Workshop Monograph. Fluids Seepages/Mud Volcanism in the Mediterranean and Adjacent Domains 29, pp. 65-71.

Gaullier, V., Mart, Y., Bellaiche, G., Mascle, J., Vendeville, B.C., Zitter, T., Benkhelil, J., Buffet, G., Droz, L., Ergun, M., Huguen, C., Kopf, A., Levy, R., Limnov, A., Shaked, Y., Volkonskaia, A., Woodside, J.M. and Prismed II Scientific Party, 2000. Salt Tectonics in and around the Nile Deep-Sea Fan. Insights from the " PRISMED II "cruise. From the Arctic to the Mediterranean: salt, shale and igneous diapirs in and around Europe. Geological Society Special Publications. pp. 111-129.

Gontharet, S., Pierre, C., Blanc-Valleron, M.-M., Rouchy, J.-M., Fouquet, G., Bayon, G., Foucher, J.-P., Woodside, J., Mascle, J., and the Nautinil Scientific party, 2007. Nature and origin of diagenetic carbonate crusts and concretions from mud volcanoes and pockmarks of the Nile deep-sea fan (Eastern Mediterranean Sea). Deep Sea Research II: Topical Studies in Oceanography 54, 1292-1311.

Huguen, C., 2001. Déformation récente à actuelle et argilo-cinèse associée au sein de la Ride Méditerranéenne (Méditerranée orientale). Thèse de doctorat, spécialité: Géologie Marine Thesis, Université P. et M. Curie (Paris 6), 260 pp.

Huguen C., Mascle J., Chaumillon E., Griboulard R., Kopf A. and Woodside J, 2004. Structural setting and tectonic control of mud volcanoes from the Central Mediterranean Ridge (Eastern Mediterranean). Marine Geology 209, 245-263.

Huguen C, Mascle J, Woodside J.M., Zitter T., and Foucher, J.-P., 2005. Mud volcanoes and mud domes of the Central Mediterranean Ridge: Near-bottom and in situ observations. Deep-Sea-Research I 52, 1911-1931.

Le Pichon, X., Chamot-Roocke, N. and Lallemant, S., 1995. Geodetic determination of the kinematics of central Greece with respect to Europe: Implications for Eastern Mediterranean Tectonics. Journal of Geophysical Research, 100: 12675-12690.

Loncke, L., 2002a. Le delta profond du Nil: structure et évolution depuis le Messinien (Miocène terminal), Thèse d'état, Université Paris 6, Spécialité Géologie Marine, 184p. 
Loncke, L., Gaullier, V., Bellaiche, G. and Mascle, J., 2002b. Recent depositional patterns of the Nile deep-sea fan from echo-character mapping. AAPG bulletin, 86(7), 1165-1186.

Loncke, L., Mascle, J., and the Fanil Scientific Party, 2004. Mud volcanoes, gas chimneys, pockmarks and mounds in the Nile deep-sea fan (eastern Mediterranean): geophysical evidences, Marine and Petroleum Geology 21, 669-689.

Loncke, L., Gaullier V., Mascle J., Vendeville, B., Camera. L., 2006. The Nile deep-sea fan: an example of interacting sedimentation, salt tectonics and inherited sub-salt paleotopographic features. Marine and Petroleum Geology 23 (3), 297-315.

Mascle, J., Benkhelil, J., Bellaiche, G., Zitter, T., Woodside, J., Loncke, L. and Prismed II Scientific Party , 2000. Marine geological evidence for a Levantine-Sinai plate, a missing piece of the Mediterranean puzzle. Geology 28(9), 779-782.

Mascle, J., Zitter, T., Bellaiche, G., Droz, L., Gaullier, V., Loncke, L., and the Prismed Scientific Party France, 2001. The Nile Deep Sea Fan; preliminary results from a swath bathymetry survey. Marine and Petroleum Geology 18, 471-477.

Mascle, J., Sardou, O., Loncke, L., Migeon, S., Camera, L., Gaullier, V., 2006. Morphostructure of the Egyptian continental margin: Insights from swath bathymetry surveys. Marine Geophysical Researches 27, 49-59.

McClusky, S., Balassanian, S., Barka, A., Demir, C., Ergintav, S., Georgiev, I., Gurkan, O., Hambyrger, M., Hurst, K., Kahla, H., Kastens, K., Kekelidze, G., King, R., Kotzev, V., Lenk, O., Mahmoud, S., Mishin, A., Nadariya, M., Ouzounis, A., Paradissis, D., Peter, Y., Prilepin, M., Reilinger, R., Sanli, I., Seeger, H., Tealeb, A., Toksöz, M.N. and Veis, G., 2000. GPS constraints on plate kinematics and dynamics in the eastern Mediterranean and Caucasus. Journal of Geophysical Research 105(B3), 5695-5719.

McKenzie, D., 1972. Active tectonics of the Mediterranean region. Geophys. Geophysical Journal of the Royal Astronomical Society, 30, 109-185.

Netzeband, G., Hubscher, C., Gajewski, D., 2006. The structural evolution of the Messinian Evaporites in the Levantine Basin. Marine Geology 230, 249-273.

Omoregie, E., Mastalerz V., de Lange G., Straub K. L., Kappler A., Røy H., Stadnitskaia A., Foucher J.P., Boetius A., 2008. Biogeochemistry and community composition of iron- and sulfide-precipitating microbial mats at the Chephren mud volcano (Nile Deep Sea Fan, Eastern Mediterranean). Applied and Environmental Microbiology, 74, 3198-3215.

Omoregie E., Niemann H., Mastalerz V., de Lange G., Stadnitskaia A., Mascle J., Foucher J.P., Boetius A. Anaerobic oxidation of methane and sulfate reduction at cold seeps in the Eastern Mediterranean Sea. Marine Geology. (this volume)

Ritger, S., Carson, B., Suess, E., 1987. Methane-derived authigenic carbonates formed by subduction-induced pore-water expulsion along the Oregon/Washington margin. Geological Society of America Bulletin 98, 147-156.

Salem, R., 1976. Evolution of Eocene-Miocene sedimentation patterns in parts of Northern Egypt. AAPG Bull 60, 34-64.

Sardou, O., and Mascle, J., 2003. Cartography by multibeam echo-sounder of the Nile deepsea fan and surrounding areas (2 sheets). Special Publication CIESM. Monaco.

Volgin A.V. and Woodside J.M., 1996. Sidescan sonar images of mud volcano from the Mediterranean Ridge : possible causes of variations in backscatter intensity. Marine Geology 132, 39-53.

\section{Figures}

Figure 1: (a) General kinematic and tectonic context of the Eastern Mediterranean basins. Grey arrows indicate relative plate motions.

(b) Multibeam bathymetry of part of the NDSF from a compilation of the PRISMED II (1998) and FANIL (2000) cruises. The various morphostructural provinces are indicated, as well as the different types of fluid escape structures (modified from Loncke et al., 2004). ESM stands for Erathosthene Seamount. 
Figure 2: (a) Color bathymetry map of the Western Central Nile Province showing locations of the Menes caldera and numerous mud cones. (b) Morphostructural interpretation of the same area.

Figure 3: (a) Backscatter map of the Menes caldera and surroundings (from the SimedMedor expedition multibeam Simrad EM 120 data). (c) 3D bathymetry block of the Menes caldera (Nautinil multibeam Simrad EM12 data).VE stands for vertical exaggeration.

Figure 4: (a) Detailed bathymetry of the Menes caldera with dive locations and main features. Pictures (1-2 $\mathbf{m}$ across) of $(\mathbf{b}, \mathbf{c}, \mathbf{d})$ carbonate crusts and $(\mathbf{e}, \mathbf{f})$ orange precipitates observed on the flanks of the mud cones.

Figure 5: (a) Dive locations and 2D interpretation map showing main seepage features on the summit of Cheops mud volcano, extrapolated from dive observations. Pictures $(1-2 \mathrm{~m}$ across) of (b) the outer edge of the brine lake showing a sharp transition to slope sediments, (c) vents covered by white bacterial mats in the central dome area, (d) dark grey spots interpreted as recent vents of muddy brine (left). Colonization by bacteria presumably increases with time elapsed since last venting (centre and right).

Figure 6: (a) Dive locations and 2D interpretation map showing main seepage features on the summit of Chephren mud volcano, extrapolated from dive observations. Pictures (1-2 m across) of (b) threads of dark grey mud and microbial filaments in the overflow area, (c) dense mats (right) and mushroom-like precipitates of bacterial origin (left) on the brine at the northern edge of the brine lake, (d) flows of almost transparent, clear brines carrying fragments of bacterial materials, (e) alternation of brine areas void of or covered by whitish bacterial filamentous materials (right and centre), dense accumulation of bacterial materials at the periphery of a void area (left), (f) sharp transition to pelagic sediment at the edge of a clear brine flow.

Figure 7: (a) Dive locations and 2D interpretation map on Mykerinos mud volcano, extrapolated from dive observations. Pictures of (b) the crater floor covered by pelagic sediment, (c) thin diagenetic carbonate pavements observed in the central part of the crater floor, (d) debris, and (e) fault scarps along the southern Menes caldera wall.

Figure 8: Sediment core samples, pictures and descriptions from (a) Cheops, (b) Chephren and (c) Mykerinos mud volcanoes.

Figure 9: SEM photographs of (a) euhedral gypsum crystal (back-scattered electrons, Chephren mud volcano, MS-52-CT from Mimes cruise, 2004), (b) micrite composed of microcrystalline aragonite needles and pyrite cementing detrital minerals and bioclasts (backscattered electrons, Mykerinos mud volcano, NL4BC1), (c) microcrystalline carbonate cement associated with acicular aragonite crystals, detrital minerals, pyrite grains and framboids (back-scattered electrons, Chephren mud volcano, NL16CC1), (d) acircular aragonite crystals infilling a void (secondary electrons, Chephren mud volcano, NL16CC1).

Figure 10: Down-core profiles of $\mathrm{SiO}_{2}$ (wt\%), $\mathrm{CaO}(w t \%), \mathrm{Fe}_{2} \mathrm{O}_{3}(w t \%)$ and Total $\mathrm{S}(\mathrm{wt} \%)$ for cores NL18-BC1, NL19-BC1 and NL19-BC2 taken at Chephren mud volcano.

Figure 11: 3D cartoon illustrating the fault-related geological control on the formation of the Menes caldera and its brine seepage activity, and the various stages of fluid activity at the three mud volcanoes. 


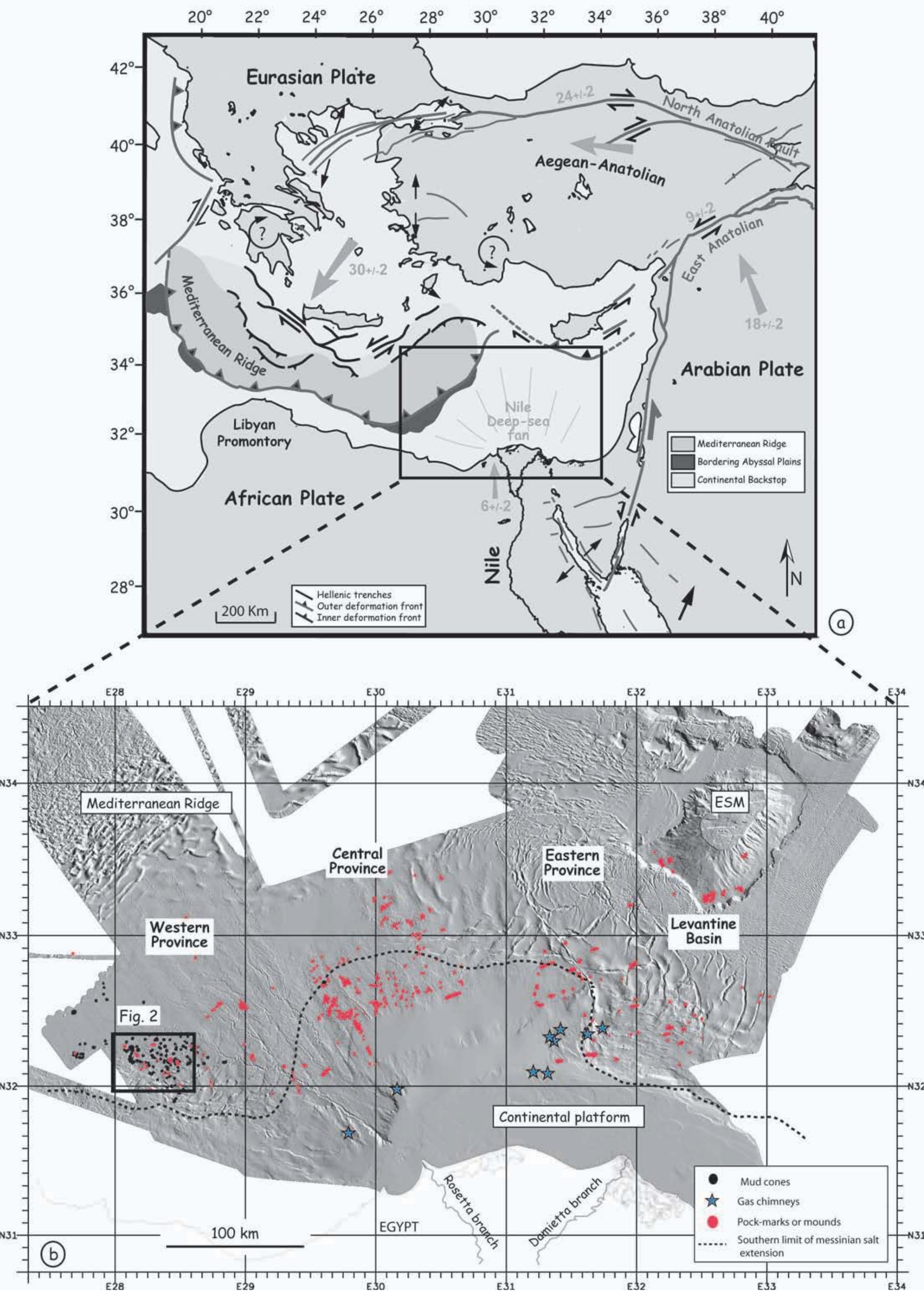





\begin{tabular}{|lll}
\hline Deep-sea channels & - Regional growth faults \\
Small scale ridges & - Counter-regional growth faults
\end{tabular} 

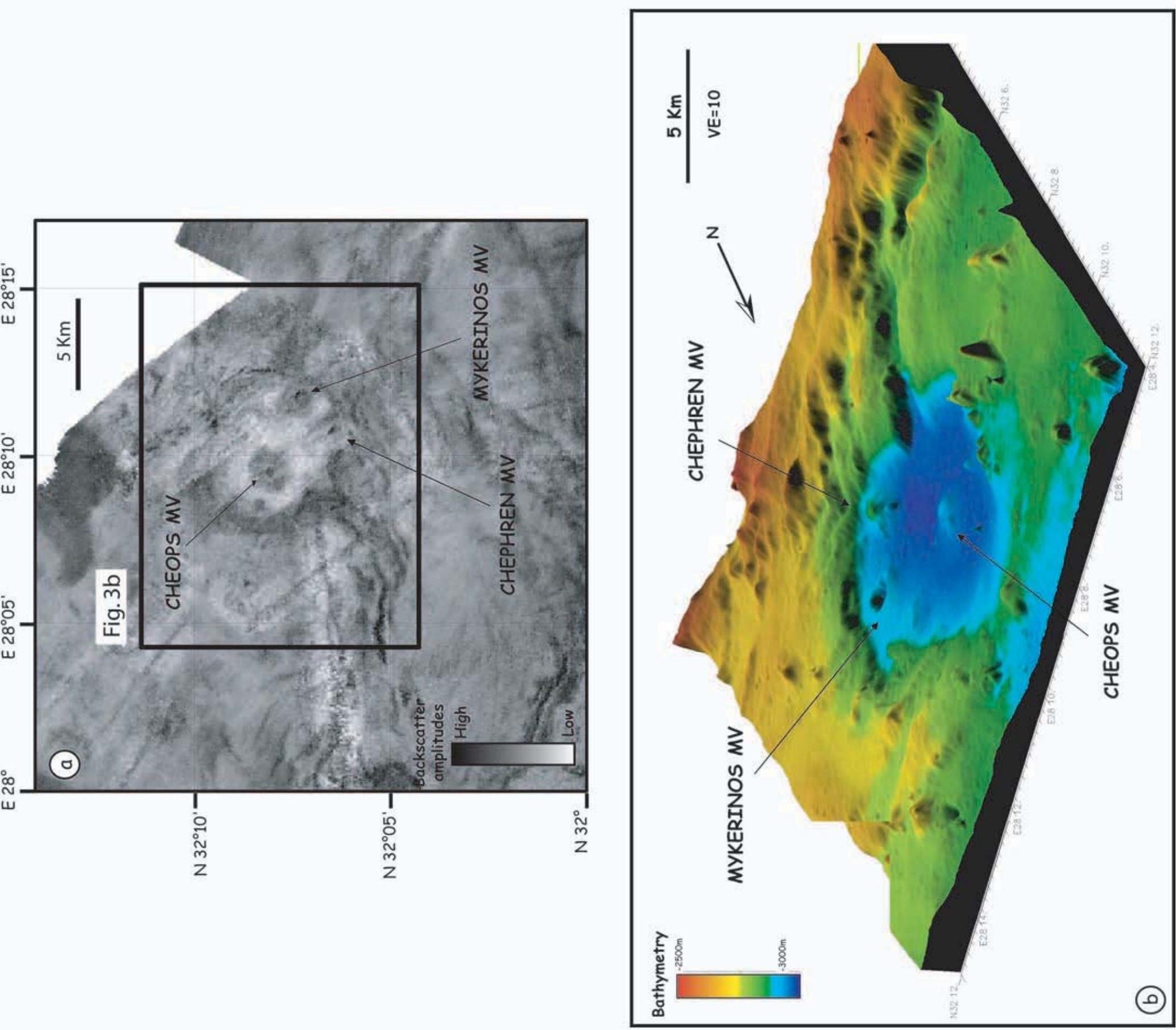


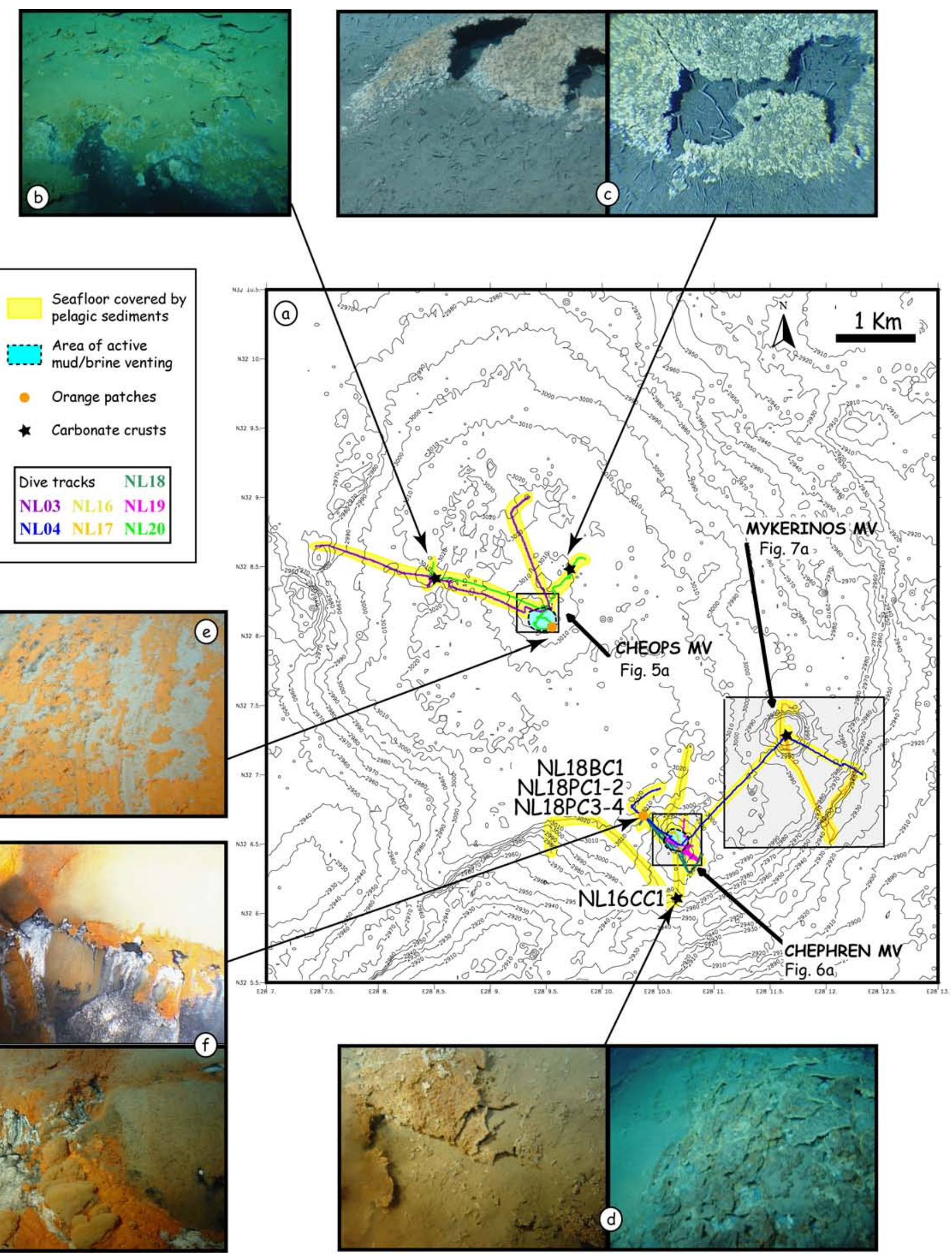


CHEPHREN Mud Volcano

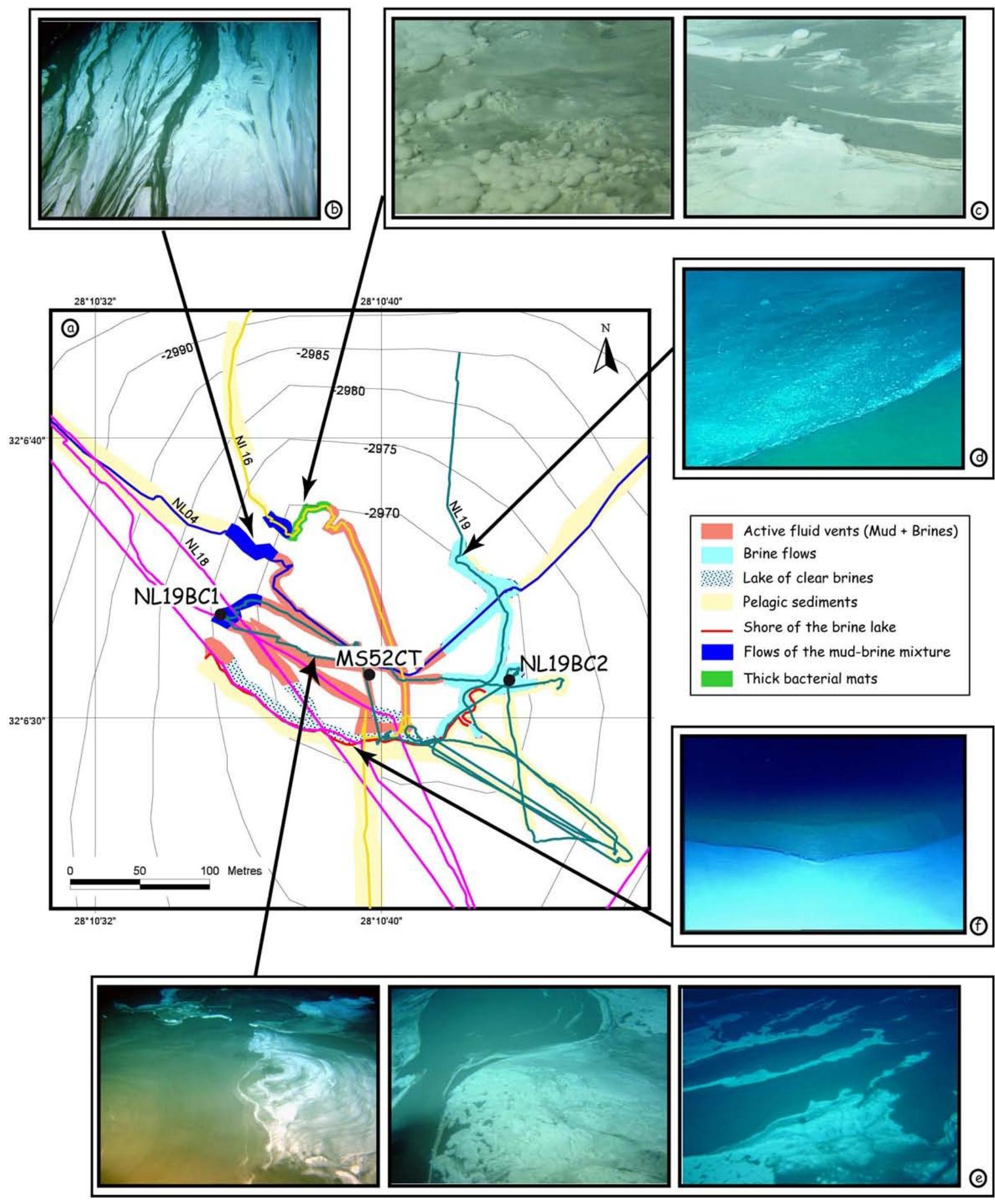


MYKERINOS Mud Volcano
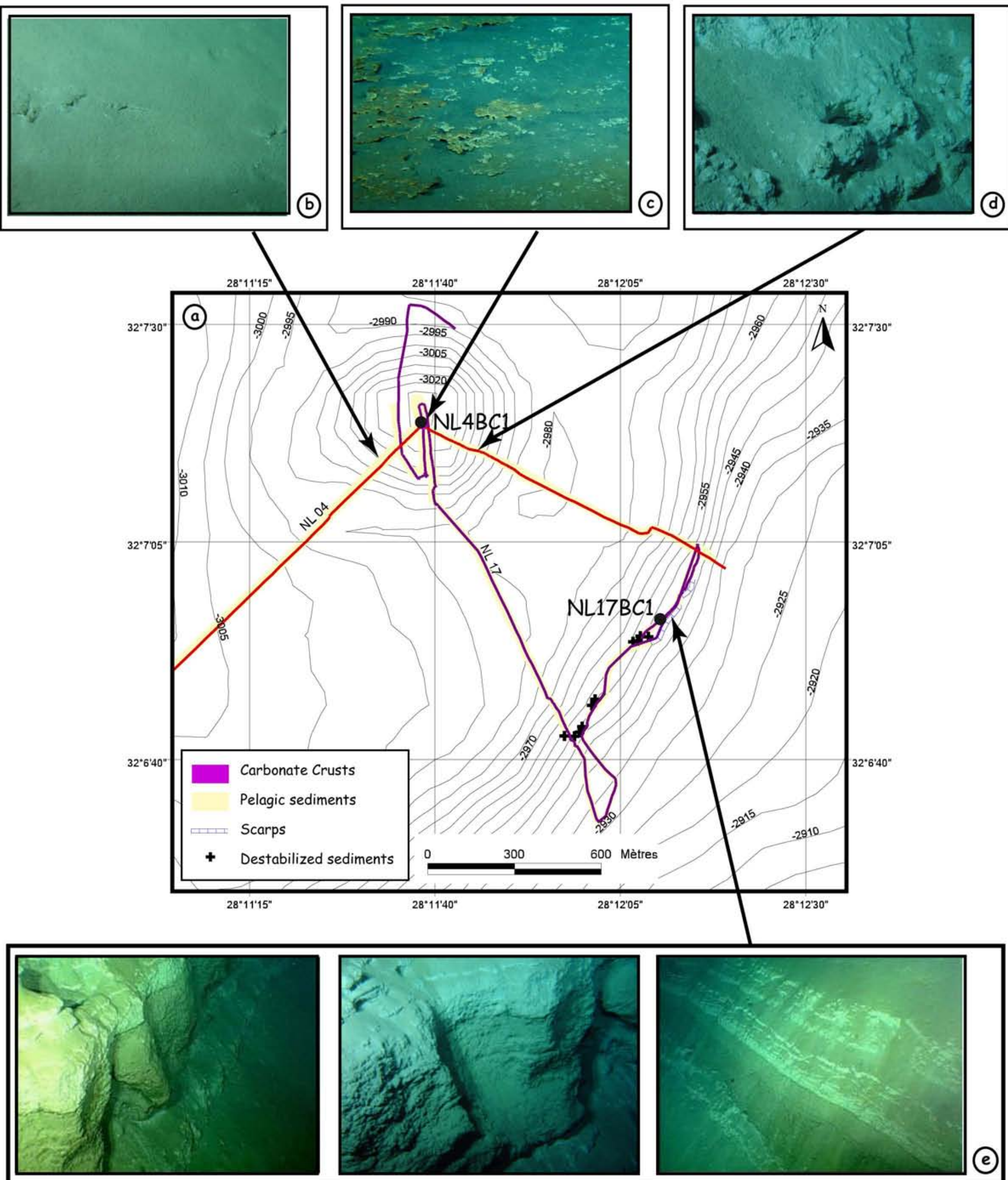



Black reduced soupy sediment (Iron Monoxides?)

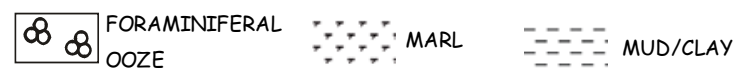

SAND/SILT 

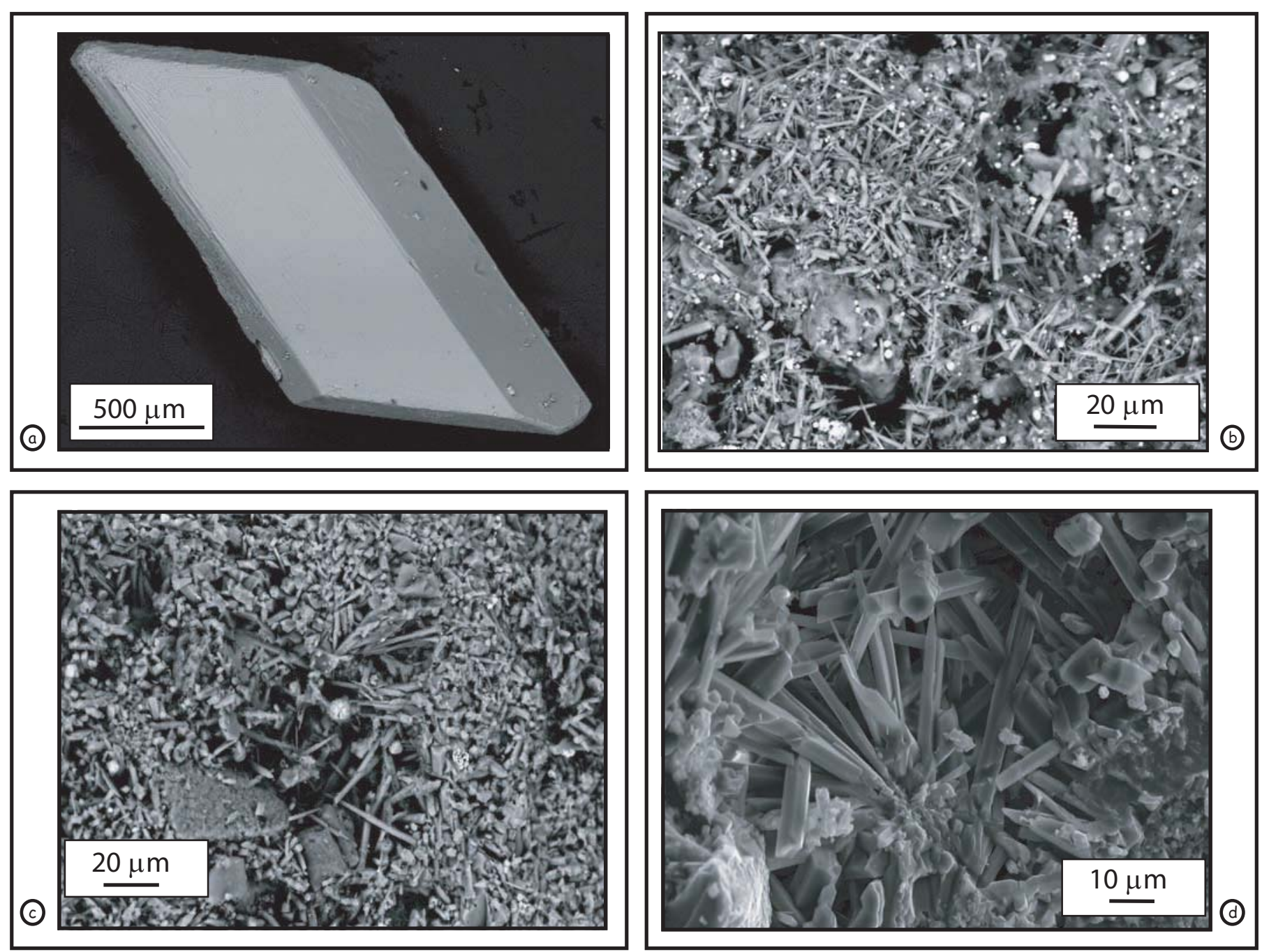


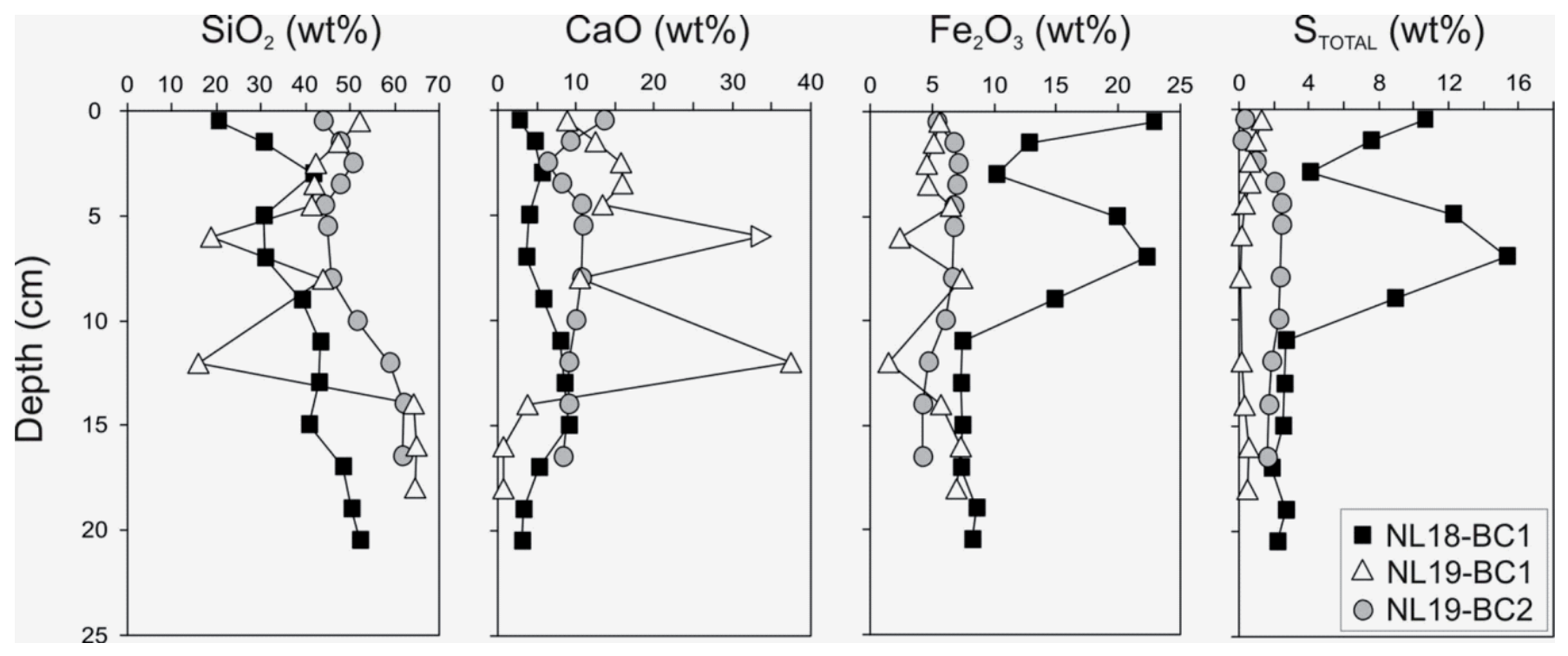




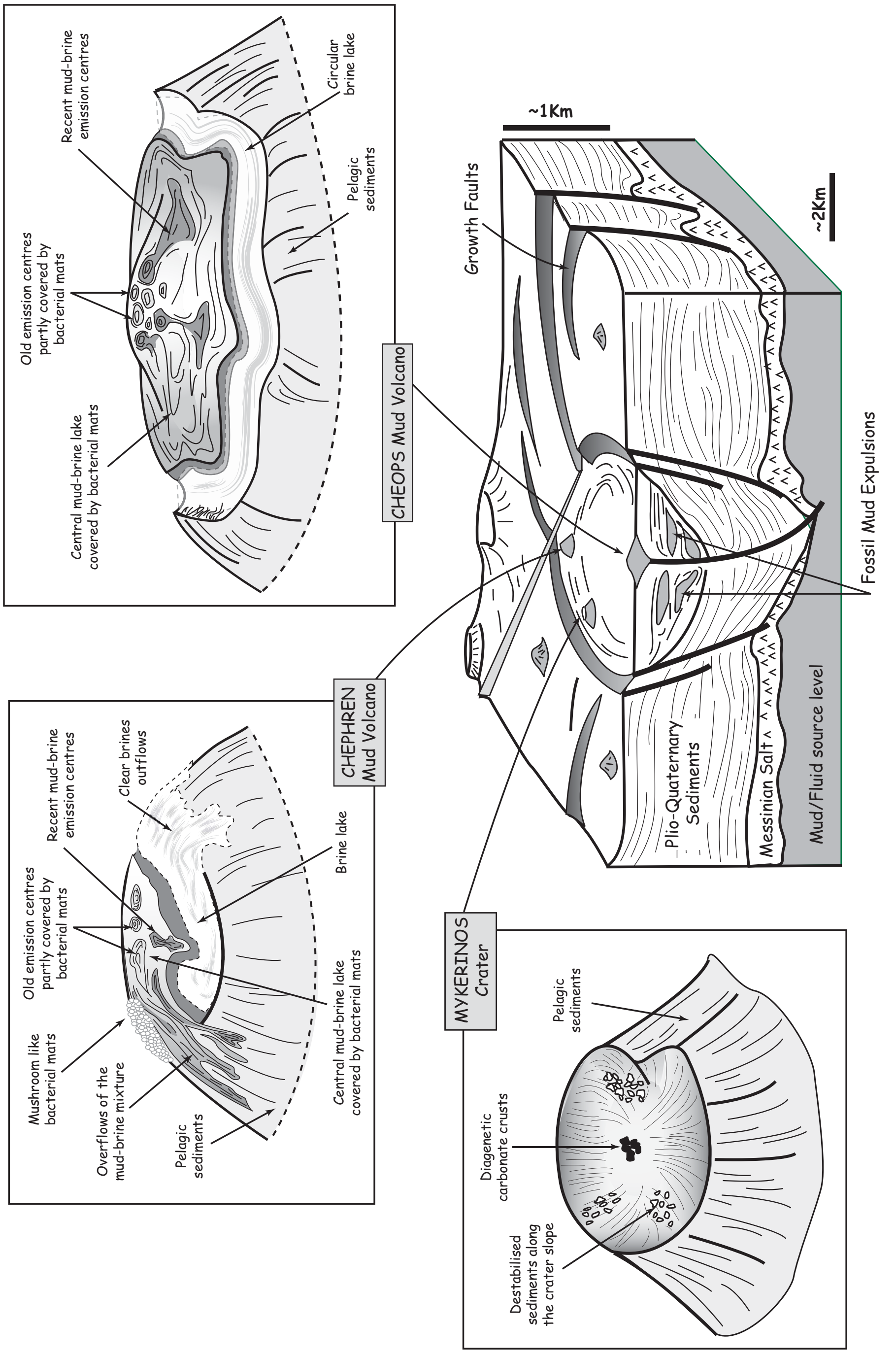

